\title{
Anatomy and plant affinity of Chuaria
}

\author{
WANG Xin ${ }^{1 *}$, YUAN XunLai $^{1}$, ZHOU ChuanMing $^{1}$, DU KaiHe ${ }^{2} \&$ GONG Miao ${ }^{1,3}$ \\ ${ }^{1}$ State Key Laboratory of Palaeobiology and Stratigraphy, Nanjing Institute of Geology and Palaeontology, Chinese Academy of Sciences, Nan- \\ jing 210008, China; \\ ${ }^{2}$ College of Biological Sciences, Nanjing Normal University, Nanjing 210046, China; \\ ${ }^{3}$ Hunan Geological Museum, Changsha 410007, China
}

Received September 6, 2010; accepted December 23, 2010

\begin{abstract}
Chuaria is one of the few globally distributed macrofossil pioneers documented in the Precambrian. It is perhaps the most controversial fossil in term of its affinity despite more than one hundred years of study. Many mutually exclusive affinities have been suggested for this frequently encountered fossil. Although often treated as a multicellular alga, this interpretation remains inconclusive because the lacking unambiguous demonstration of cellular structures. In this paper the cellular details of Chuaria are clearly revealed for the first time. The cell walls in Chuaria suggest that it is a multicellular eukaryotic alga, in agreement with the latest biogeochemical analyses. Different thicknesses of cell walls suggest primary cellular differentiation in this organism. Membrane-like structures within the cells (the first to be reported in Precambrian fossils) imply a eukaryotic nature. This study partially resolves the century-long controversy over the affinity of Chuaria, and makes Chuaria one of the few recognized multicellular eukaryotes before the Neoproterozoic glaciation.
\end{abstract}

Chuaria, plant, cell wall, multicellular, eukaryote, membrane

Citation: $\quad$ Wang X, Yuan X L, Zhou C M, et al. Anatomy and plant affinity of Chuaria. Chinese Sci Bull, 2011, 56: 1256-1261, doi: 10.1007/s11434-011-4370-x

The genus Chuaria was established by Walcott in 1899. It includes circular carbonaceous discs found in the Chuar Group in the United States [1]. Later studies indicate that Chuaria occurs from the Palaeoproterozoic to the Neoproterozoic in China, the United States, Canada, India, Australia, Africa, and other regions, and that it is an important fossil organism in the Precambrian biota [2-19]. Since the erection of the genus by Walcott, more than 10 mutually exclusive affinities have been suggested for Chuaria, including an inorganic structure, a dubiofossil of unknown origin, a brachiopod, a gastropod, a chitinous foraminiferid, a hyolithid operculum, a trilobite egg, a juvenile medusoid, an alga, a cyst, a spore sac, or an acritarch [1-19]. The controversy over Chuaria persists mainly because of a dearth of anatomical or cellular evidence and most of the hypotheses are based on morphological comparisons and speculations. This uncertainty hinders further understanding on Chuaria

*Corresponding author (email: brandonhuijunwang@gmail.com) and its role in the Proterozoic ecosystem. In this paper specimens of Chuaria collected from the Neoproterozoic in the Anhui Province, China are studied from a new perspective. The combination of replica techniques, light microscopy (LM), scanning electron microscopy (SEM) and transmission electron microscopy (TEM) reveals cellular details and the affinity of the fossils. Membrane-like structures are reported for the first time in Chuaria.

The Neoproterozoic succession of the southeastern margin of the North China Block is well exposed in the Anhui Province. In the Huainan region of northern Anhui, it unconformably overlies gneisses and schists of the probable Archean-aged Fengyang Group and disconformably underlies the trilobite-bearing Lower Cambrian strata of the Houjiashan Formation [20]. In an ascending order, the succession consists of the Bagongshan, Liulaobei, Shouxian, Jiuliqiao, Sidingshan, and Fengtai Formations [18].

Near Shouxian, the Liulaobei Formation at the DiangedaBaieshan section is $\sim 530 \mathrm{~m}$ thick. The upper part of the 
Liulaobei Formation is composed of yellowish green shales that are interbedded with thin beds of quartz sandstone, calcareous siltstone, and argillaceous limestones, with the limestone interbeds becoming increasingly abundant toward the top of the section (Figure 1b). The formation yields abundant leiospheroid acritarchs [21] and macroscopic carbonaceous compression fossils such as Chuaria, Tawuia, Ellipsophysa, and Sinosabellidites [20,22,23]. Conformably overlying the Shouxian Formation, the Jiuliqiao Formation ( 71 m thick) consists mainly of thin-bedded argillaceous limestone, and stromatolitic limestone, with calcareous siltstone intercalations. Macroscopic carbonaceous compression fossils, including Chuaria, Ellipsophysa, Sinosabellidites, Pararenicola, and Protoarenicola, are abundant in this formation [18,20,22,23]. The formation also contains a large quantity of leiospheroid acritarch [24].

Recent Sm-Nd dating of diagenetic chert from the Sidingshan Formation yielded an isochron age of $801 \pm 46 \mathrm{Ma}$ [25], and SHRIMP zircon U-Pb measurements on dolerites that intrude the Huaibei Neoproterozoic succession in the region provided ages of $976 \pm 24 \mathrm{Ma}$ and $1038 \pm 26 \mathrm{Ma}$ [26]. The acritarchs of the Liulaobei Formation are comparable to those of the late Riphean (Neoproterozoic) pre-Cryogenian assemblages well known from Europe and North America [21]. Taken together, these observations suggest that fossiliferous Liulaobei and Jiuliqiao Formations are pre-Cryogenian in age.

\section{Materials and methods}

The fossils were collected from the Jiuliqiao and Liulaobei Formations, Shouxian, Anhui Province, China (Figure 1a,b). The specimens were first observed and photographed with an Aigo digital viewer. Replicas were made on some of the specimens [27], demineralized with $\mathrm{HCl}-\mathrm{HF}-\mathrm{HCl}$, coated with gold, and observed using a Leo $1530 \mathrm{VP}$ SEM at the Nanjing Institute of Geology and Palaeontology, Nanjing, China (NIGP). For comparison, a sample collected from a Triassic cycad leaf was processed and observed in the same way. EDXMA (energy dispersive X-ray microanalysis) on both Chuaria and its sediment matrix was carried out using the same SEM. A total of 14 specimens were observed using the SEM. Afterwards the replica was embedded in SPIPon812 resin, ultrathin-sectioned, stained with lead citrate, and observed using a Hitachi-7650 TEM at Nanjing Normal University, Nanjing, China. All Chuaria specimens are deposited in NIGP, while the fossil cycad is deposited in Shenzhen Fairy Lake Botanical Garden, Shenzhen, China (SFLBG). All micrographs were saved in TIFF format, and prepared for publication using Adobe Photoshop 7.0.

\section{Results}

The specimens of Chuaria were embedded in the yellowish slightly calcareous siltstone of the Liulaobei (Figure 2a-h)

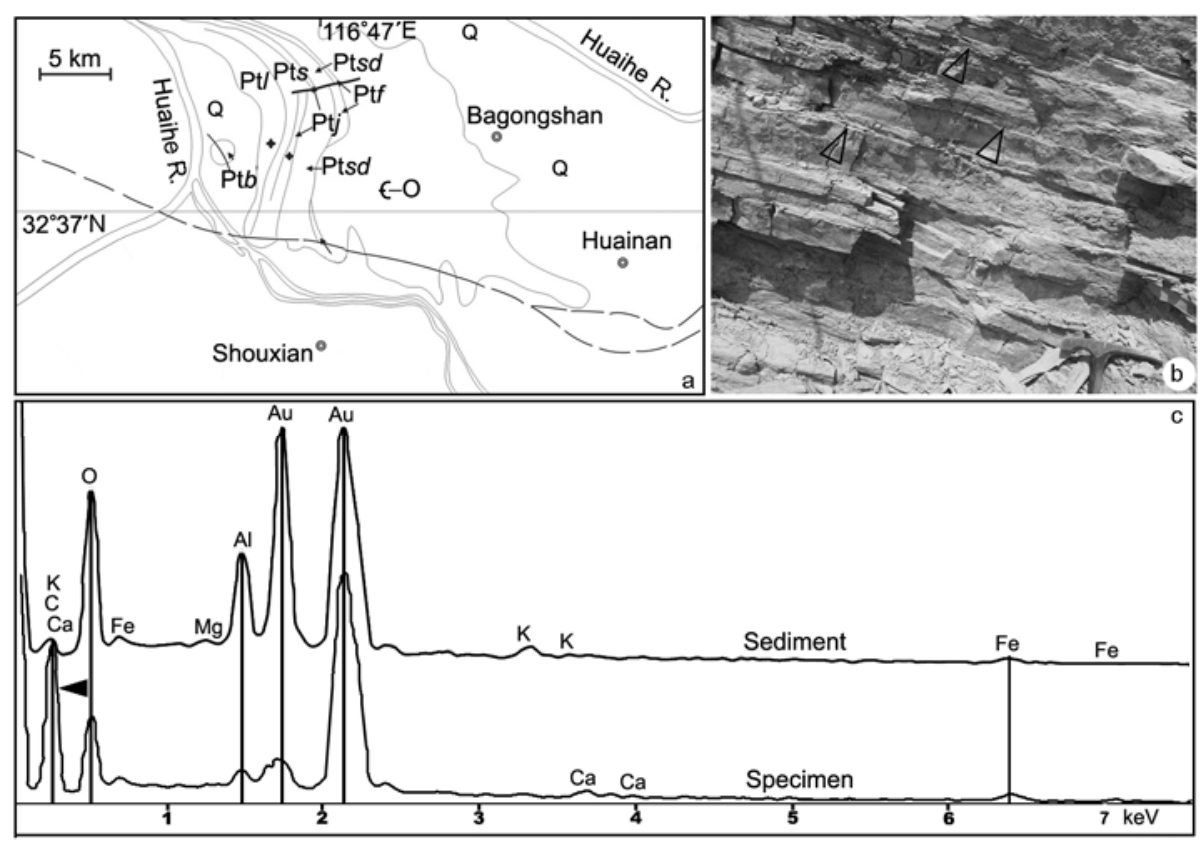

Figure 1 Basic information concerning the specimens studied. a, Geological map of the fossil localities in the Huainan region, northern Anhui Province. Pt $b$ : Bagongshan Formation; Pt $l$ : Liulaobei Formation; Pts: Shouxian Formation; Ptj: Jiuliqiao Formation; Ptsd: Sidingshan Formation; Pt $f$ : Fengtai Formation; E-O: Cambrian to Ordovician; Q: Quaternary; b, thin-bedded limestones in the uppermost Liulaobei Formation. Arrows point to the layers yielding Chuaria; c, Energy dispersive X-ray microanalyses on Chuaria and its sediment matrix. Note that carbon (black triangle) is almost completely absent in the sediment while it is abundant in the specimen, suggesting the biological source of the specimen. 
and Jiuliqiao Formations (Figure 3a-g) in Shouxian, Anhui Province, China. They were circular, $1.47-1.95 \mathrm{~mm}$ in diameter, or oval, up to $4.5 \mathrm{~mm} \times 6.5 \mathrm{~mm}$, preserved as dark organic compressions (Figures 2a,b; 3a,f). Replicas made on the specimens were cleaned with $\mathrm{HCl}-\mathrm{HF}-\mathrm{HCl}$, coated with gold and observed using SEM (Figures 2c-h; 3b,g). The organic materials appear dark brown or black in color under the light microscope (Figures 2a-b; 3a,f). Organic material in all fourteen of the specimens observed by SEM consistently revealed preserved cellular details (Figures $2 \mathrm{c}-\mathrm{h}$; $3 b-e, g)$. The cells were polygonal in profile, 10-32 $\mu \mathrm{m}$ long and 3.6-18 $\mu \mathrm{m}$ wide (Figures $2 \mathrm{~d}-\mathrm{h} ; 3 \mathrm{~b}, \mathrm{~g}$ ). The cells were separated by cell walls (Figures $2 \mathrm{e}, \mathrm{h} ; 3 \mathrm{~b}, \mathrm{~g}$ ), which varied in thicknesses (Figures $2 \mathrm{e}, \mathrm{h} ; 3 \mathrm{~b}, \mathrm{~g}$ ). The cells with thin walls were either slightly flattened, isodiametric polygons, or highly flattened, more or less elongate polygons (Figures 2e; 3b,g). The thin cell walls appear as a thin sheet about $100 \mathrm{~nm}$ thick, either sandwiched between cells or, where the adjacent cell had detached, the cell wall was perforated with holes $350 \mathrm{~nm}$ to $1 \mu \mathrm{m}$ in diameter in surface view (Figures $2 \mathrm{e}-\mathrm{h} ; 3 \mathrm{~b}, \mathrm{~g}$ ). The thick cell walls, frequently seen at the margin of the specimen, were up to $2 \mu \mathrm{m}$ thick
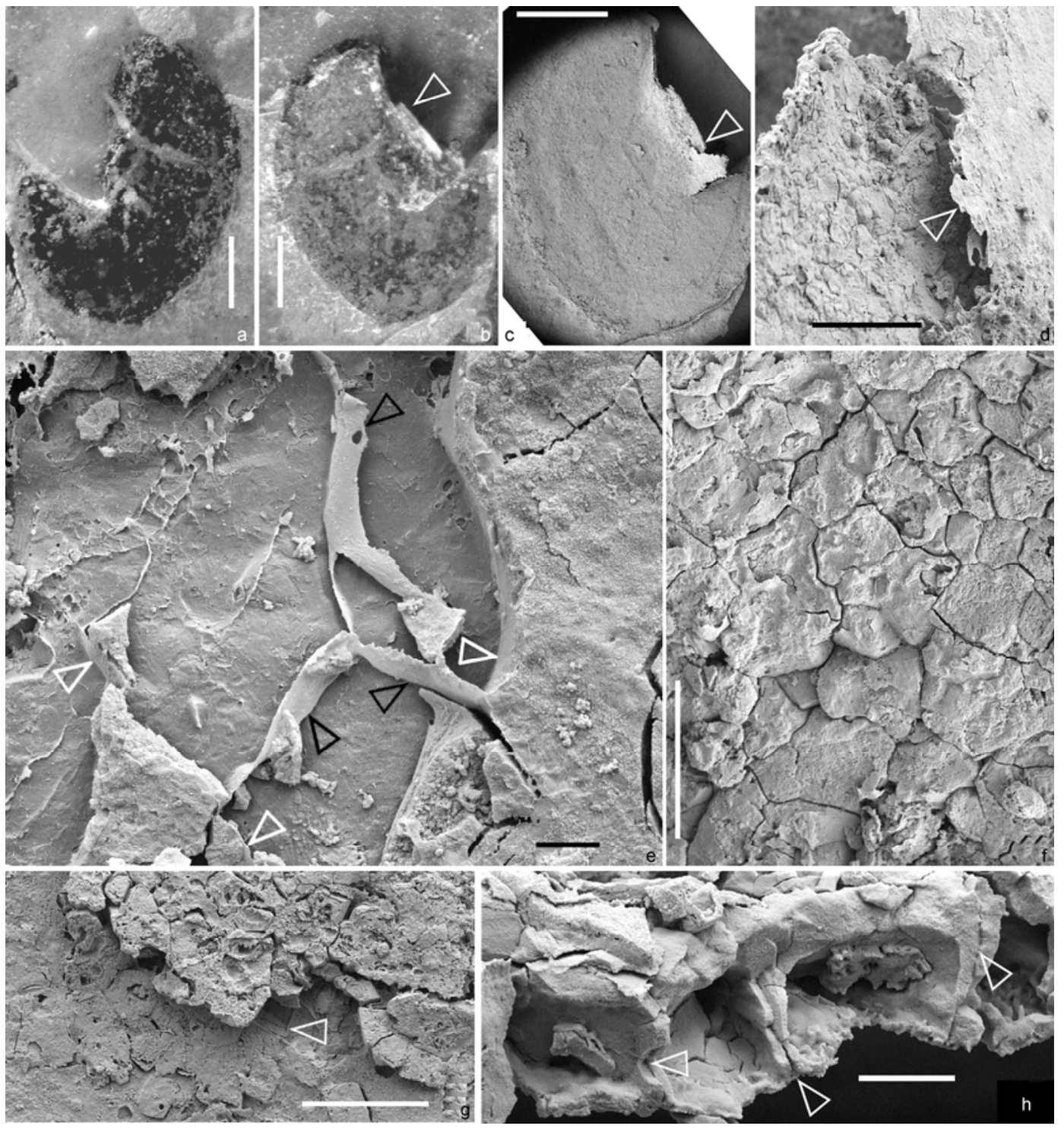

Figure 2 A specimen of Chuaria still attached to sediment and its cellular details. Specimen number PB21277, deposited in NIGP. a and b are LM, all others are SEM. a, A general view of the specimen. Note the upper-left corner of the specimen is still covered in the sediments. Bar $=1 \mathrm{~mm}$. b, A replica made from the specimen. Note the portion formerly covered by sediments in Figure $2 \mathrm{a}$ (arrow) is now standing on the replica. Bar $=1 \mathrm{~mm}$. $\mathrm{c}$, An SEM view of the replica. Bar $=1 \mathrm{~mm}$. d, A detailed view of the portion arrowed in Figure 2c. Note there are at least two layers of tissue (one arrowed and the other to the left). Bar $=0.1 \mathrm{~mm}$. e, Free-standing thin cell walls (black arrows) and cell walls adhering to the cells (white arrow). Note the hole on the cell wall marked by the topmost black arrow. Bar $=5 . \mu \mathrm{m}$. f, Cells enlarged from the left piece of tissue in Figure 2d. Note the blocks of organic materials (cells). Bar $=50 \mu \mathrm{m} . \mathrm{g}$, Multiple layers of cells in the specimen. Note the polygonal outlines of the cells and the cell wall (arrow) of the cells in the layer beneath. Bar = $0.1 \mathrm{~mm}$. h, An oblique view of the broken surface near the arrow in Figure 2c. Note the thick cell walls between two lumina and the fissure between the adjacent cell walls (arrows). Bar $=10 \mu \mathrm{m}$. 
(Figure 2h). Adjacent thick cell walls were not completely fused but were separated by a fissure (Figure $2 \mathrm{~h}$ ). Sometimes membrane-like structures were observed in the cells (Figure 3c-e). These membrane-like structures appeared different in sections at different levels of the same region in the same cell, suggesting a three-dimensional configuration (Figure 3d,e). Energy dispersive X-ray microanalyses performed on Chuaria and its sediment matrix indicated that the fossils were composed of organic material rich in carbon and distinct from the sediment matrix (Figure 1c). The above mentioned cells and cell walls of Chuaria were similar to those seen in a Triassic cycad leaf (Figure 3h,i), in which the cells appeared as blocks of organic material sandwiching thin two-dimensional cell walls (Figure 3i). There were also pits on the cell walls when the cells were removed (lower-left corner of Figure 3i).

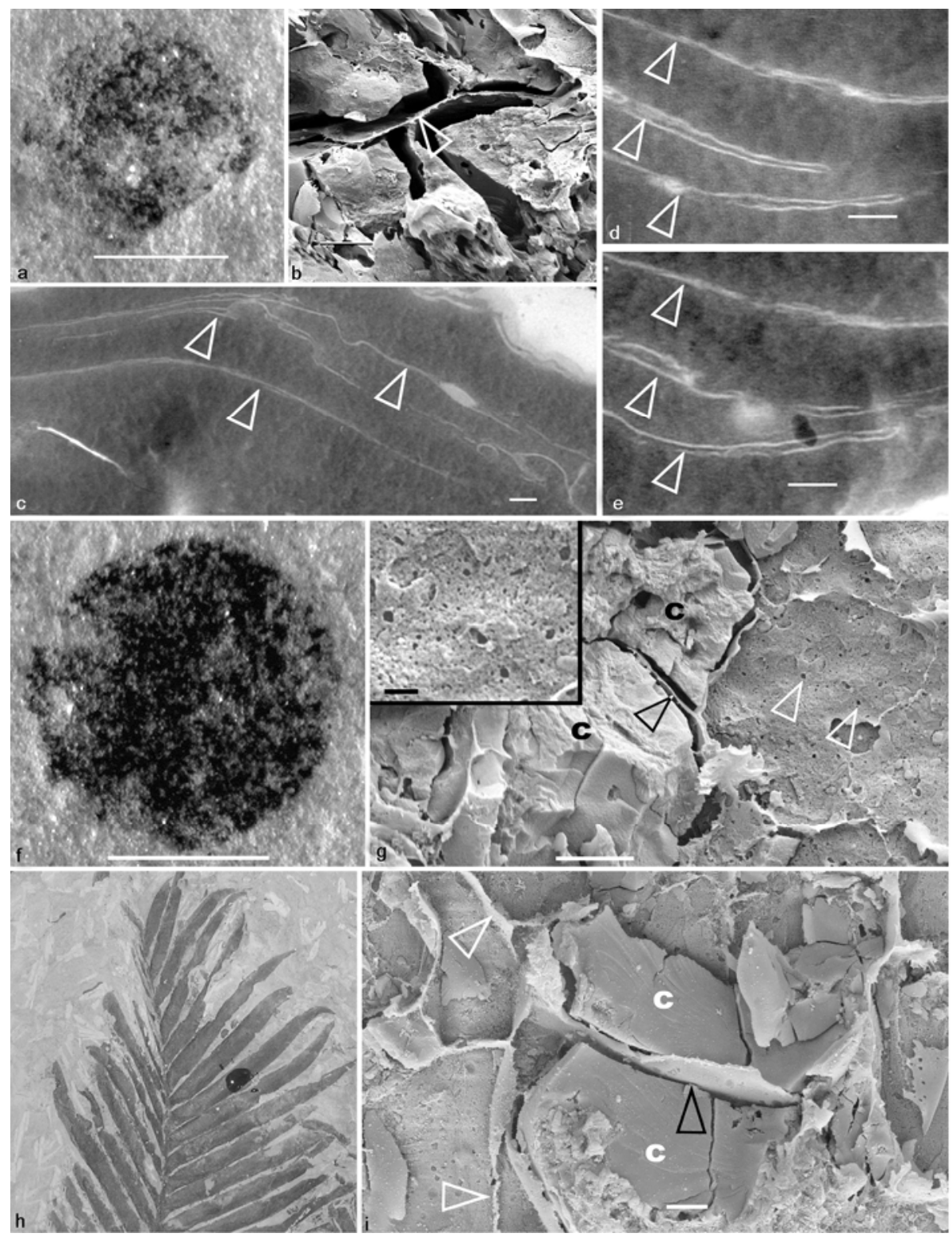

Figure 3 Specimens of Chuaria with cellular details and ultrastructures, and their comparison with those of a fossil cycad. a-e (PB21279) and $\mathrm{f}-\mathrm{g}$ (PB21278), deposited in NIGP; h-i (LNFC-2007-001), deposited in SFLBG. All are SEM except Figure 3a, f, h (LM) and Figure c-e (TEM). Figure 3b, g and $\mathrm{i}$ is of replicas. a, A circular specimen with dark organic material. Bar $=1 \mathrm{~mm}$. b. Cells with cell walls (white arrow) sandwiched between them. Bar $=5$ $\mu \mathrm{m}$. c, Several layers of membrane-like structures in the cells. Bar $=100 \mathrm{~nm}$. d, e, The same membrane-like structures in the same cell. Note the subtle difference between the corresponding structures (arrows) at different levels. Bar $=100 \mathrm{~nm}$. f, A specimen of dark organic material. Note its circular shape and the dark organic material. Bar $=1 \mathrm{~mm}$. g, A broken surface showing cells (C), cell walls in cross- (black arrow) and surface-views (at the right), and pits on the cell walls (white arrows). The inset shows a detailed view of the pits, with a $1 \mu \mathrm{m}$ bar. Bar $=5 \mu \mathrm{m}$. h, A Triassic cycad (Holozamites hongtaoi [28]) leaf from western Liaoning, China. Note the dark drop of the liquid that latter condenses into the replica showed in Figure 3i. i, Cells with preserved organic material in the cycad leaf. Note the cell walls (black arrow) either sandwiched between cells (C) or freely standing where the cells have detached (white arrows), and cell wall with pits in surface view (lower-left corner). 


\section{Discussion}

Chuaria is a circular, discoidal fossil of millimeter dimensions, consisting of carbonaceous compressions. It is also one of the oldest known macroscopic body fossils [7]. Despite its long history of study, the biological affinity of Chuaria has been problematic for a variety of reasons. Well-preserved coalified specimens of Chuaria were studied here using the replica technique to reveal cellular details. This technique makes a faithful impression of cellular structures, which also may bring some organic material with intact cellular features to be studied and demonstrated clearly using SEM and TEM (Figures 2c-h; 3b-e,g). The thin cell walls appeared as sheets of organic material sandwiched between cells (Figures $2 \mathrm{e} ; 3 \mathrm{~b}, \mathrm{~g}$ ). This was confirmed by observation on original samples that had cleaned with $\mathrm{HCl}$ and thus, eliminated the possibility of artifacts introduced by the replica technique. The space between the cells and their cell walls may reflect the original difference in organization and differentiated shrinkage in the fossils, and this space remained unfilled despite subsequent compression. This space is distinct from the previously reported cracks in the "amorphous" envelope of Chuaria (see Plate 4, Figure 2 in Steiner [10]), which lacked a cell wall between the adjacent blocks. Disturbance during demineralization and rinsing may have detached cells that were weakly associated with their cell walls, leaving the cell walls intact and exposed in surface view (Figures 2e, h; 3g).

An alternative interpretation that the putative cell walls were simply resulted from in-filling between cells (or blocks of organic material) appears implausible because (1) cell walls were restricted only to regions where organic fossil material was preserved and were completely absent from areas lacking fossil material; (2) inorganic in-filling would be expected to fill the gaps between cells or blocks rather than to leave spaces between them; (3) inorganic in-filling, if present, would have been dissolved to some degree during the demineralizing process. The congruence between observations before and after demineralization suggests that, in this case, the cell wall was composed of organic material derived from the organisms themselves. Most of the thin cell walls appeared as sheets of organic material about 80-150 nm thick, and their thickness was independent of the gap between cells. An inorganic in-filling, if present, would be expected to have a thickness closely correlated with the gap dimension; (4) pits were frequently observed on the cell walls (Figures 2e; 3g). They appeared as irregularly scattered circular holes on the cell wall, quite similar to those seen in another cycad fossil plant (lower-left corner in Figure 3i). Their existence suggests possible communication channels (pits and plasmodesmata) between these cells, which are a feature of eukaryotes. Their presence is hard to explain by inorganic infilling; (5) the thick cell walls (Figure $3 \mathrm{~h}-\mathrm{i}$ ) framed concave lumina, just like those of living plants; (6) some of the thick cell walls were composed of two layers (Figure $2 \mathrm{~h}$ ) apparently representing two adjacent cell walls. This phenomenon cannot be attributed to inorganic infilling between organic materials but compares well with cell walls in living plants; and (7) membrane-like structures within the cells of Chuaria (Figure 3c-e) were very similar to the ER or other membranes seen in other much younger fossil plants [29-36]. These membrane-like structures suggest strongly a eukaryotic nature of Chuaria. In short, the constant and coherent spatial relationships among the cells, cell walls, pits on the cell walls, and membrane-like structures in the cells of Chuaria are similar to those in extant and fossil plants and suggest that cell walls are an authentic feature of Chuaria. These cellular details indicate that Chuaria belongs to the plant kingdom.

There are many features that distinguish plants from animals, e.g. the presence of chlorophyll and chloroplasts, vacuoles, and cell wall. Among these, cell wall is by far the most idiosyncratic anatomical feature that can be used to distinguish plants from animals. The presence of cell walls in Chuaria eliminates the possibility that it is an animal. Its multicellularity, pits on cell walls, and membrane-like structures eliminate the possibility of it being a prokaryote, as suggested previously $[11,12]$. The cells with thick cell walls were observed only at the margins of the organism, suggesting a possible role in retaining the form of the organism (as in living plants) (Figure 2h). This observation is in accord with Amard's study [8] on Chuaria although his conclusion concerning its affinity is different from ours. The latest geobiochemical studies indicate that Chuaria contains aliphatic biogeopolymer, suggesting an algal origin, which is in agreement with our conclusion [17,19]. Although the threedimensional distribution of the cell types in the organism is still unclear, the presence of different types of cells implies that there is a primary cellular differentiation in Chuaria.

Many fossils of similar age and morphology have been regarded as Chuaria. Many of them differ from the present observations, especially in their dimensions. Therefore it is likely that not all fossils named as Chuaria belong to the same biological taxon. However, the consistent SEM observations on all fourteen specimens of Chuaria studied here certainly suggest that all of these macroscopic Chuaria belong to the plant kingdom. It is logical to assume that Chuaria has an important role as a primary producer in the Proterozoic ecosystem.

There are relatively few well-recognized multicellular macroscopic eukaryotes recorded for the period before the Neoproterozoic glaciation [37-40]. Our study indicates that these discoid Chuaria were important eukaryotic elements during the Proterozoic, and that they represent the evolutionary level of the multicellular eukaryotes at that time.

We thank Dr. Li Nan and SFLBG for access to the cycad specimen, Wang Chunzhao, Zhuo Erjun, and He Cuiling for their help in fossil processing. We thank two anonymous reviewers for their constructive suggestions. This 
work was supported by the Knowledge Innovation Program of the Chinese Academy of Sciences (KZCX2-YW-153,154), the National Natural Science Foundation of China (40772006, 40625006, 40632010 and J0630967), the State Key Laboratory of Palaeobiology and Stratigraphy, Nanjing Institute of Geology and Palaeontology (20102108 and 20101104), and the Scientific Research Foundation for the Returned Overseas Chinese Scholars, State Education Ministry.

1 Walcott C D. Pre-Cambrian fossiliferous formations. Bull Geol Soc Amer, 1899, 10: 199-244

2 Gussow W C. Chuaria sp. cf. C. circularis Walcott from the Precambrian Hector Formation, Banff National Park, Alberta, Canada. J Paleontol, 1973, 47: 1108-1112

3 Jux U. Über die Wandstructuren sphaeromorpher Acritarchen: Tasmanites Newton, Tapajonites Sommer and van Bökel, Chuaria Walcott. Paläontographica B, 1977, 160: 1-16

4 Zheng W. A new occurrence of fossil group of Chuaria from the Sinian System in north Anhui and its geological meaning. Bull Tianjin Inst Geol Min Res, 1980, 1: 49-69

5 Duan C. Late Precambrian algal megafossils Chuaria and Tawuia in some areas of eastern China. Alcheringa, 1982, 6: 57-68

6 Hofmann H J. The Mid-Proterozoic Little Dal macrobiota, Mackenzie Mountains, Northwest Canada. Palaeontology, 1985, 28: 331-354

7 Sun W. Palaeontology and biostratigraphy of late Precambrian macroscopic colonial algae: Chuaria Walcott and Tawuia Hofmann. Paläontographica B, 1987, 203: 109-134

8 Amard B. Ultrastructure of Chuaria (Walcott) Vidal and Ford (Acritarch) from the Late Proterozoic Pendjari Formation, Benin and Burkina-Faso, West Africa. Precambrian Res, 1992, 57: 121-133

9 Hofmann H J. Proterozoic carbonaceous compressions ("metaphytes" and "worms"). In: Bengtson S, ed. Early Life on Earth. New York: Columbia University Press, 1994. 342-357

10 Steiner M. Die neoproterozoischen Megaalgen Südchinas. Berl Geowiss Abhandl E, 1994, 15: 1-146

11 Steiner M. Chuaria circularis Walcott 1899 - "megasphaeromorph acritarch" or prokaryotic colony? Acta Univ Carol Geol, 1997, 40: 645-665

12 Sharma M, Shukla M. Carbonaceous megaremains from the Neoproterozoic Owk Shales Formation of the Kurnool Group, Andhra Pradesh, India. Curr Sci, 1999, 76: 1247-1250

13 Zhu S, Sun S, Huang X, et al. Discovery of carbonaceous compressions and their multicellular tissues from the Changzhougou Formation (1800 Ma) in the Yanshan Range, North China. Chinese Sci Bull, 2000, 45: 841-846

14 Kumar S. Mesoproterozoic megafossil Chuaria-Tawuia association may represent parts of a multicellular plant, Vindhyan Supergroup, Central India. Precambrian Res, 2001, 106 187-211

15 Yuan X, Xiao S, Yin L, et al. Doushantuo Fossils: Life on the Eve of Animal Radiation. Hefei: University of Science and Technology of China Press, 2002

16 Kumar S, Srivastava P. Carbonaceous megafossils from the Neoproterozoic Bhander Group, Central India. J Palaeontol Soc Ind, 2003, 48 139-154

17 Dutta S, Steiner M, Banerjee S, et al. Chuaria circularis from the early Mesoproterozoic Suket Shale, Vindhyan Supergroup, India: Insights from light and electron microscopy and pyrolysis-gas chromatography. J Earth Syst Sci, 2006, 115: 99-112

18 Dong L, Xiao S, Shen B, et al. Restudy of the worm-like carbonaceous compression fossils Protoarenicola, Pararenicola, and $\mathrm{Si}$ nosabellidites from early Neoproterozoic successions in North China. Palaeogeogr Palaeoclimatol Palaeoecol, 2008, 258: 138-161
19 Sharma M, Mishra S, Dutta S, et al. On the affinity of ChuariaTawuia complex: A multidisciplinary study. Precambrian Res, 2009, 173: $123-136$

20 Wang G, Zhang S, Li S, et al. Research on the Upper Precambrian of Northern Jiangsu and Anhui Provinces. Hefei: Anhui Press of Science and Technology, 1984

21 Yin L, Sun W. Microbiota from the Neoproterozoic Liulaobei Formation in the Huainan region, northern Anhui, China. Precambrian Res, 1994, 65: 95-114

22 Xing Y, Duan C, Liang Y, et al. Late Precambrian Palaeontology of China. Beijing: Geological Publishing House, 1985

23 Sun W, Wang G, Zhou B. Macroscopic worm-like body fossils from the Upper Precambrian (900-700 Ma), Huainan district, Anhui, China and their stratigraphic and evolutionary significance. Precambrian Res, 1986, 31: 377-403

24 Hong T, Jia Z, Yin L, et al. Acritarchs from the Neoproterozoic Jiuliqiao Formation, Huainan region, and their biostratigraphic significance. Acta Palaeontol Sin, 2004, 43: 377-387

25 Yang J, Zheng W, Tao X, et al. The Sm-Nd age of cherts from Sidingshan Formation of the Huainan Group of Anhui Province. Geol Rev, 2004, 50: 413-417

26 Liu Y, Gao L, Liu X, et al. Zircon U-Pb age determination of early Neoproterozoic mafic magmatic event in the Xu-Huai region. Chinese Sci Bull, 2005, 51: 2375-2382

27 Zhu W. The use of the peeling method in palaeobotanical studies. Chin Bull Bot, 1983, 1: 51-53

28 Wang X, Li N, Wang Y, et al. The discovery of whole-plant fossil cycad from the Upper Triassic in western Liaoning and its significance. Chinese Sci Bull, 2009, 54: 3116-3119

29 Niklas K J, Brown R M, Santos R, et al. Ultrastructure and cytochemistry of Miocene angiosperm leaf tissues. Proc Natl Acad Sci USA, 1978, 75: 3263-3267

30 Niklas K J, Brown R M. Ultrastructural and paleobiochemical correlations among fossil tissue from the St. Maries River (Clarkia) area, Northern Idaho, USA. Amer J Bot, 1981, 68: 332-341

31 Poinar H N, Melzer R R, Poinar G O. Ultrastructure of 30-40 million-year-old leaflets from Dominican amber (Hymenaea protera, Fabaceae: Angiospermae). Experientia, 1996, 52: 387-390

32 Schönhut K, Vann D R, LePage B A. Cytological and ultrastructural preservations in Eocene Metasequoia leaves from the Canadian High Arctic. Amer J Bot, 2004, 91: 816-824

33 Koller B, Schmitt J M, Tischendorf G. Cellular fine structures and histochemical reactions in the tissue of a cypress twig preserved in Baltic amber. Proc Roy Soc B, 2005, 272: 121-126

34 Wang X, Cui J. The first observation on plant cell fossils in China. Acta Geol Sin, 2007, 81: 16-22

35 Wang X, Liu W, Cui J, et al. Paleontological evidence for membrane fusion between a unit membrane and a half-unit membrane. Mol Membr Biol, 2007, 24: 496-506

36 Wang X, Liu W, Du K. Palaeontological evidence of membrane relationship in step-by-step membrane fusion. Mol Membr Biol, 2011, 28: $115-122$

37 Butterfield N J, Knoll A H, Swett K. A bangiophyte red alga from the Proterozoic of Arctic Canada. Science, 1990, 250: 104-107

38 Butterfield N J. Bangiomorpha pubescens n. gen., n. sp.: implications for the evolution of sex, multicellularity, and the Mesoproterozoic/Neoproterozoic radiation of eukaryotes. Paleobiology, 2000, 26: 386-404

39 Butterfield N J. Paleobiology of the late Mesoproterozoic (ca. 1200 Ma) Hunting Formation, Somerset Island, Arctic Canada. Precambrian Res, 2001, 111: 235-256

40 Butterfield N J. Probable Proterozoic fungi. Paleobiology, 2005, 31: $165-182$

Open Access This article is distributed under the terms of the Creative Commons Attribution License which permits any use, distribution, and reproduction in any medium, provided the original author(s) and source are credited. 